\title{
The Discovery of Clinical Development Candidate GDC- 0084, a Brain Penetrant Inhibitor of PI3K and mTOR
}

Timothy P. Heffron, * Chudi O. Ndubaku, Laurent Salphati, Bruno Alicke, Jonathan Cheong, Joy Drobnick, Kyle Edgar, Stephen E. Gould, Leslie B. Lee, John D. Lesnick, Cristina Lewis, Jim Nonomiya, Jodie Pang, Emile G. Plise, Steve Sideris, Jeffrey Wallin, Lan Wang, Xiaolin Zhang, Alan G. Olivero.

\section{Supporting Information}

In vitro Kinase Selectivity for 16.

Class I PI3Ks ${ }^{1}$ :

$$
\begin{aligned}
& \mathrm{PI} 3 \mathrm{~K} \alpha \mathrm{Ki}_{\text {app }}=2 \mathrm{nM} \\
& \mathrm{PI} 3 \mathrm{~K} \beta \mathrm{Ki}_{\text {app }}=46 \mathrm{nM} \\
& \mathrm{PI} 3 \mathrm{~K} \delta \mathrm{Ki}_{\text {app }}=3 \mathrm{nM} \\
& \mathrm{PI} 3 \mathrm{~K} \gamma \mathrm{Ki}_{\text {app }}=10 \mathrm{nM} \\
& \text { mTOR Ki }
\end{aligned}
$$

$\begin{array}{ll}\begin{array}{l}\text { Panel of 229 Kinases } \\ \text { tested at 1uM 16 } \\ \text { (Invitrogen) }\end{array} & \\ \text { Kinase } & \\ \text { ACVR1B } & \text { \%inhib. } \\ \text { AKT1 } & 1.1 \\ \text { AKT2 } & 0.7 \\ \text { AKT3 } & 6.1 \\ \text { ALK } & 5.9 \\ \text { Abl } & 2.3 \\ \text { Arg } & 2.0 \\ \text { Aurora_A } & 14.1 \\ \text { Aurora_B } & 3.2 \\ \text { Aurora_C } & -9.1 \\ \text { Axl } & -2.5 \\ \text { B-Raf } & 6.0 \\ \text { Blk } & 7.6 \\ \text { Bmx } & 28.8 \\ \text { BrSK1 } & 20.8 \\ \end{array}$




\begin{tabular}{|c|c|}
\hline Brk & 5.9 \\
\hline CDK1/cyclinB & 3.3 \\
\hline CDK2/cyclinA & -2.4 \\
\hline CDK5/p25 & 0.3 \\
\hline CDK5/p35 & 7.5 \\
\hline CDK7/cyclinH & 2.4 \\
\hline CDK9/cyclinT1 & -0.9 \\
\hline CHK1 & 0.6 \\
\hline CHK2 & 11.3 \\
\hline CK1_alpha1 & 1.9 \\
\hline CK1_epsilon1 & 4.8 \\
\hline CK1_gamma1 & 6.8 \\
\hline CK1_gamma2 & 1.4 \\
\hline CK1_gamma3 & -0.2 \\
\hline CK2_alpha1 & 3.2 \\
\hline CK2_alpha2 & 2.3 \\
\hline CLK1 & 4.0 \\
\hline CLK2 & 5.3 \\
\hline CLK3 & 7.0 \\
\hline CSF1R & 21.9 \\
\hline CSK & 10.0 \\
\hline CaMKI & -1.4 \\
\hline CaMKII_beta & 0.2 \\
\hline CaMKI_delta & 11.6 \\
\hline CamKII_alpha & 2.1 \\
\hline CamKII_delta & -1.4 \\
\hline CamKIV & 0.2 \\
\hline Cot & 28.7 \\
\hline DAPK1 & -1.2 \\
\hline DCAMKL2 & 3.3 \\
\hline DNA-PK & 17.7 \\
\hline DYRK1A & 2.8 \\
\hline DYRK1B & -2.7 \\
\hline DYRK3 & -10.8 \\
\hline DYRK4 & 4.6 \\
\hline EGFR & 2.5 \\
\hline ERK1 & 8.6 \\
\hline ERK2 & 5.2 \\
\hline EphA1 & 7.8 \\
\hline EphA2 & -0.7 \\
\hline EphA4 & 3.0 \\
\hline EphA5 & 5.9 \\
\hline EphA8 & 6.9 \\
\hline EphB1 & 1.9 \\
\hline EphB2 & 6.6 \\
\hline EphB3 & -0.1 \\
\hline EphB4 & 4.8 \\
\hline ErbB2 & 8.5 \\
\hline ErbB4 & 7.0 \\
\hline FAK & -1.9 \\
\hline
\end{tabular}




\begin{tabular}{|c|c|}
\hline FAK2 & 4.6 \\
\hline FGFR1 & -6.8 \\
\hline FGFR2 & 2.3 \\
\hline FGFR3 & 11.5 \\
\hline FGFR4 & 5.8 \\
\hline Fer & 8.9 \\
\hline Fes & -10.1 \\
\hline Fgr & 37.2 \\
\hline Flt1 & 0.6 \\
\hline Flt3 & 21.9 \\
\hline Flt4 & 4.8 \\
\hline Frk & 8.0 \\
\hline Fyn & 9.0 \\
\hline GCK & 0.9 \\
\hline GRK2 & -3.6 \\
\hline GRK3 & 4.6 \\
\hline GRK4 & -4.2 \\
\hline GRK5 & -10.0 \\
\hline GRK6 & 2.9 \\
\hline GRK7 & -9.5 \\
\hline GSK3_alpha & 2.5 \\
\hline GSK3_beta & 1.0 \\
\hline HIPK1 & 3.3 \\
\hline HIPK2 & 1.6 \\
\hline HIPK4 & 2.6 \\
\hline Haspin & 3.8 \\
\hline Hck & 34.0 \\
\hline Hyl & 3.3 \\
\hline IGF1R & 4.9 \\
\hline IKK_alpha & -3.8 \\
\hline IKK_beta & 2.3 \\
\hline IKK_epsilon & 2.9 \\
\hline IRAK4 & 10.2 \\
\hline IRR & 11.5 \\
\hline InsR & 6.0 \\
\hline Itk & 9.6 \\
\hline JAK1 & -1.6 \\
\hline JAK2 & 15.2 \\
\hline JAK3 & 8.9 \\
\hline JNK1_alpha1 & -4.2 \\
\hline JNK2 & 9.8 \\
\hline JNK3 & -2.7 \\
\hline KDR & -3.6 \\
\hline KHS1 & 1.5 \\
\hline Kit & 14.1 \\
\hline LRRK2 & 10.1 \\
\hline LTK & 7.8 \\
\hline Lck & 38.0 \\
\hline Lyn & 23.3 \\
\hline LynB & 24.9 \\
\hline
\end{tabular}




$\begin{array}{ll}\text { MAPKAPK2 } & 1.1 \\ \text { MAPKAPK3 } & 4.4 \\ \text { MARK1 } & 4.4 \\ \text { MARK2 } & 5.5 \\ \text { MARK3 } & 4.3 \\ \text { MARK4 } & 1.5 \\ \text { MEK1 } & -0.1 \\ \text { MEK2 } & 8.1 \\ \text { MELK } & -10.4 \\ \text { MLK1 } & 28.9 \\ \text { MRCK_alpha } & -4.5 \\ \text { MSK1 } & 10.9 \\ \text { MSK2 } & 0.6 \\ \text { MSSK1 } & 11.1 \\ \text { MST1 } & 5.0 \\ \text { MST2 } & -2.0 \\ \text { MST3 } & -1.3 \\ \text { MST4 } & -1.5 \\ \text { MYLK2(skMLCK) } & 3.0 \\ \text { Mer } & 8.1 \\ \text { Met } & 6.5 \\ \text { Mink1 } & 14.3 \\ \text { MuSK } & 12.7 \\ \text { NEK1 } & -6.4 \\ \text { NEK2 } & 20.0 \\ \text { NEK4 } & 7.8 \\ \text { NEK6 } & 13.1 \\ \text { NEK7 } & -0.3 \\ \text { NEK9 } & -2.6 \\ \text { PAK1 } & 7.0 \\ \text { PAK2 } & 3.5 \\ \text { PAK3 } & 3.0 \\ \text { PAK4 } & -4.5 \\ \text { PAK6 } & 15.2 \\ \text { PAK7 } & 15.3 \\ \text { PASK } & 18.6 \\ \text { PDGFR_alpha } & -5.3 \\ \text { PDGFR_beta } & 9.7 \\ \text { PDK1 } & 4.8 \\ \text { PDK1(direct) } & 13.4 \\ \text { PI3KC2a } & -8.8 \\ \text { PI3KC2b } & 13.2 \\ \text { PI3KC3_hVPS34 } & 42.6 \\ \text { PI4Ka } & 23.6 \\ \text { PI4Kb } & 7.0 \\ \text { PIM1 } & 2.8 \\ \text { PIM2 } & -4.4 \\ \text { PKA } & \\ \text { PKC_alpha } & \\ \text { PKC_beta1 } & \end{array}$




\begin{tabular}{|c|c|}
\hline PKC_beta2 & 11.9 \\
\hline PKC_delta & 1.7 \\
\hline PKC_epsilon & 10.7 \\
\hline PKC_eta & -9.0 \\
\hline PKC_gamma & 23.8 \\
\hline PKC_iota & 6.8 \\
\hline PKC_theta & 5.8 \\
\hline PKC_zeta & 1.6 \\
\hline PKD $\overline{1}$ & 1.6 \\
\hline PKD2 & 4.5 \\
\hline PKD3 & 19.9 \\
\hline PKG1_alpha & -3.4 \\
\hline PKG2 & 12.1 \\
\hline PLK1 & 3.3 \\
\hline PLK2 & 7.2 \\
\hline PLK3 & -4.8 \\
\hline PRK1 & -12.7 \\
\hline PRKAA1 & 9.3 \\
\hline PRKAA2 & 5.8 \\
\hline PhK_gamma1 & 2.0 \\
\hline PhK_gamma2 & 0.0 \\
\hline $\operatorname{PrKX}$ & 8.3 \\
\hline RAF1(Y340D,Y341D) & 42.3 \\
\hline ROCK1 & 1.3 \\
\hline ROCK2 & -16.1 \\
\hline Ret & 13.4 \\
\hline Ron & 8.0 \\
\hline Ros & -6.7 \\
\hline Rse & 3.6 \\
\hline Rsk1 & -4.6 \\
\hline Rsk2 & 1.4 \\
\hline Rsk3 & 4.4 \\
\hline Rsk4 & 27.4 \\
\hline SGK1 & 13.9 \\
\hline SGK2 & 2.8 \\
\hline SGK3 & -3.5 \\
\hline SIK2 & 6.8 \\
\hline SPHK1 & -2.8 \\
\hline SPHK2 & -2.3 \\
\hline SRPK1 & 5.5 \\
\hline SRPK2 & -7.7 \\
\hline Src & 29.9 \\
\hline Src_N1 & 43.6 \\
\hline Srm & -1.1 \\
\hline Syk & 42.8 \\
\hline TAO1 & -1.3 \\
\hline TBK1 & 4.0 \\
\hline TSSK1 & 5.5 \\
\hline TSSK2 & -6.8 \\
\hline TYK2 & 8.4 \\
\hline
\end{tabular}




$\begin{array}{ll}\text { Tie2 } & 7.4 \\ \text { TrkA } & 7.3 \\ \text { TrkB } & 4.2 \\ \text { TrkC } & 11.7 \\ \text { YSK1 } & -8.8 \\ \text { Yes } & 31.3 \\ \text { ZAP-70 } & -0.9 \\ \text { eEF-2K } & 5.2 \\ \text { p38_alpha } & -9.4 \\ \text { p38_alpha(direct) } & 4.3 \\ \text { p38_beta } & 6.5 \\ \text { p38_delta } & 12.1 \\ \text { p38_gamma } & 11.9 \\ \text { p70S6K } & 6.0\end{array}$

Inhibition of pAKT and pS6 in U87 cells.

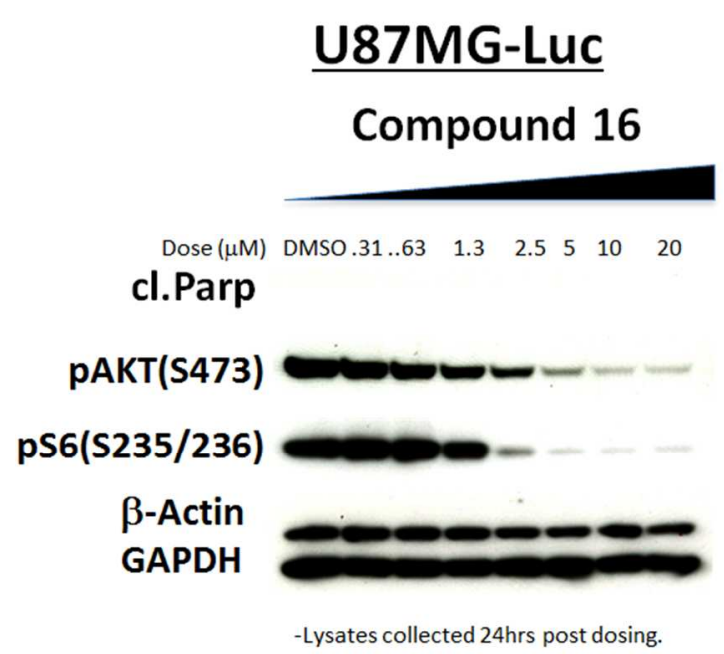

Characterization of Biochemical and Cellular Activity in vitro. Enzymatic activity of $\mathrm{PI} 3 \mathrm{~K} \alpha$ was measured using a fluorescence polarization assay that monitors formation of the product 3,4,5-inositoltriphosphate molecule (PIP3) as it competes with fluorescently labeled PIP3 for binding to the GRP-1 pleckstrin homology domain protein. An increase in phosphatidyl inositide-3-phosphate product results in a decrease in fluorescence polarization signal as the labeled fluorophore is displaced from the GRP-1 protein binding site. PI3Ka was purchased from Perkin Elmer or was expressed and purified as heterodimeric recombinant protein. Tetramethylrhodamine-labeled PIP3 (TAMRA-PIP3), di-C8-PIP2, and PIP3 detection reagents 
were purchased from Echelon Biosciences. PI3Ka was assayed under initial rate conditions in the presence of $10 \mathrm{mM}$ Tris (pH 7.5), $25 \mathrm{uM} \mathrm{ATP,} 9.75 \mathrm{uM}$ PIP2, $5 \%$ glycerol, $4 \mathrm{mM} \mathrm{MgCl}$, $50 \mathrm{mM} \mathrm{NaCl}, 0.05 \%$ (v/v) Chaps, $1 \mathrm{mM}$ dithiothreitol, $2 \%(\mathrm{v} / \mathrm{v})$ DMSO at a $60 \mathrm{ng} / \mathrm{mL}$ concentration of $\mathrm{PI} 3 \mathrm{~K} \alpha$. After assay for $30 \mathrm{~min}$ at $25^{\circ} \mathrm{C}$, reactions were terminated with a final concentration of $9 \mathrm{mM}$ EDTA, $4.5 \mathrm{nM}$ TAMRA-PIP3, and $4.2 \mathrm{ug} / \mathrm{mL}$ GRP-1 detector protein before reading fluorescence polarization on an Envision plate reader. $\mathrm{IC}_{50}$ 's were calculated from the fit of the dose-response curves to a 4-parameter equation. Apparent Ki values, where measured, were determined at a fixed concentration of ATP near the measured Km for ATP for PI $3 \mathrm{~K} \alpha$, and were calculated by fitting of the dose-response curves to an equation for tightbinding competitive inhibition. All $\mathrm{IC}_{50}$ 's and apparent $\mathrm{Ki}$ values represent geometric means of at least three determinations. These assays generally produced results within 2-fold of the reported mean.

Human recombinant mTOR(1360-2549) was expressed and purified from insect cells and assayed using a Lanthascreen fluorescence resonance energy transfer format from Invitrogen in which phosphorylation of recombinant green fluorescent protein (GFP)-4-EBP1 is detected using a terbium-labeled antibody to phospho-threonine 37/46 of 4-EBP1. Reactions were initiated with ATP and conducted in the presence of $50 \mathrm{Mm}$ Hepes (pH 7.5), $0.25 \mathrm{nM}$ mTOR, $400 \mathrm{nM}$ GFP-4E-BP1, $8 \mu \mathrm{M}$ ATP, $0.01 \%(\mathrm{v} / \mathrm{v})$ Tween $20,10 \mathrm{mM} \mathrm{MnCl} 2,1 \mathrm{mM}$ EGTA, $1 \mathrm{mM}$ dithiothreitol, and $1 \%(\mathrm{v} / \mathrm{v})$ DMSO. Assays were conducted under initial rate conditions at room temperature for $30 \mathrm{~min}$ before terminating the reaction and detecting product in the presence of 2 nM Tb-anti-p4E-BP1 antibody and 10 mM EDTA. Dose-response curves were fit to an equation for competitive tight-binding inhibition and apparent $\mathrm{K}_{i}$ 's were calculated using the determined 
$\mathrm{K}_{\mathrm{m}}$ for ATP of $6.1 \mu \mathrm{M}$. All apparent Ki values represent geometric means of minimum of two determinations. These assays generally produced results within 2-fold of the reported mean.

Anti-proliferative cellular assays were conducted using PC3 human tumor cell lines provided by the ATCC. Cell lines were cultured in RPMI supplemented with $10 \%$ fetal bovine serum, 100 units $/ \mathrm{mL}$ penicillin, and $100 \mu \mathrm{g} / \mathrm{mL}$ streptomycin, $10 \mathrm{mM}$ HEPES and $2 \mathrm{mM}$ Glutamine at $37^{\circ} \mathrm{C}$ under $5 \% \mathrm{CO}_{2}$. PC3 cells were seeded in 384-well plates in media at 1000 cells/well or 3000 cells/well, respectively, and incubated overnight prior to the addition of compounds to a final DMSO concentration of $0.5 \% \mathrm{v} / \mathrm{v}$. PC3 cells were incubated for 3 and 4 days, respectively, prior to the addition of CellTiter-Glo ${ }^{\circledR}$ reagent (Promega) and reading of luminescence using an Analyst plate reader. For anti-proliferative assays, a cytostatic agent such as aphidicolin and a cytotoxic agent such as staurosporine were included as controls. Dose-response curves were fit to a 4-parameter equation and relative $\mathrm{EC}_{50}$ 's were calculated using Assay Explorer or Genedata software. All cellular $\mathrm{EC}_{50}$ values represent geometric means of a minimum of at least two determinations and these assays generally produced results within 3-fold of the reported mean.

In Vitro Transport Assays. Madin-Darby canine kidney (MDCK) cells heterologously expressing human P-gp, human BCRP or mouse Bcrp1 and LLC-PK1 cells transfected with mouse P-gp (mdr1a) were used to determine whether compounds are substrate of these transporters. MDR1-MDCKI cells were licensed from the NCI (National Cancer Institute, Bethesda, MD) while Bcrp1-MDCKII, BCRP-MDCKII and Mdr1a-LLC-PK1 cells were obtained from the Netherlands Cancer Institute (Amsterdam, The Netherlands). For transport studies, cells were seeded on 24-well Millicell plates (Millipore, Billerca, MA) 4 days prior to use (polyethylene terephtalate membrane, $1 \mu \mathrm{M}$ pore size) at a seeding density of $2.5 \times 10^{5}$ cells $/ \mathrm{mL}$ (except for MDR1-MDCKI, $1.3 \times 10^{5}$ cells $/ \mathrm{mL}$ ). Compounds were tested at $5 \mu \mathrm{M}$ in the 
apical to basolateral (A-B) and basolateral to apical (B-A) directions. The compounds were dissolved in transport buffer consisting of Hank's balanced salt solution (HBSS) with $10 \mathrm{mM}$ HEPES (Invitrogen Corporation, Grand Island, NY). Lucifer Yellow (Sigma-Aldrich, St. Louis, MO) was used as the paracellular marker. Compound concentrations in the donor and receiving compartments were determined by LC-MS/MS analysis. The apparent permeability $\left(\mathrm{P}_{\text {app }}\right)$, in the apical to A-B and B-A directions, was calculated after a 2-hour incubation as:

$P_{\text {app }}=(d Q / d t) \bullet\left(1 / A C_{0}\right)$

Where: $\mathrm{dQ} / \mathrm{dt}=$ rate of compound appearance in the receiver compartment; $A=$ Surface area of the insert; $\mathrm{C}_{0}=$ Initial substrate concentration at $\mathrm{TO}$.

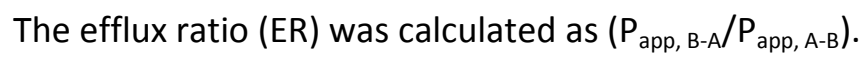

All efflux ratios reported represent the arithmetic mean of a minimum of at least two determinations and these assays generally produced results within $50 \%$ of the reported mean.

Determination of plasma protein and brain binding. The extent of protein binding was determined in vitro, in mouse plasma (Bioreclamation, Inc., Hicksville, NY) by equilibrium dialysis using a HTDialysis 96-well block (HTDialysis ${ }^{\circledR}$ LLC; Gales Ferry, CT). The compound was added to pooled plasma from multiple animals $(\mathrm{n} \geq 3)$ at a total concentration of $10 \mu \mathrm{M}$. Plasma samples were equilibrated with phosphate-buffered saline $(\mathrm{pH} 7.4)$ at $37^{\circ} \mathrm{C}$ in $90 \%$ humidity and $5 \% \mathrm{CO}_{2}$ for 4 hours. Following dialysis, concentration of compounds in plasma and buffer were measured by LC-MS/MS. The percent unbound in plasma was determined by dividing the concentration measured in the post-dialysis buffer by that measured in the postdialysis plasma and multiplying by 100. Incubations were performed in triplicate and coefficient of variation is not greater than $30 \%$. 
The free fraction in mouse brain was determined as described by Kalvass. ${ }^{2}$ Briefly, brain tissue was homogenized in 3 volumes of phosphate-buffered saline and compound was added at a final concentration of $10 \mu \mathrm{M}$. Aliquots of $300 \mu 1$ were dialyzed in a RED device (Thermo Scientific, Rockford, IL) against a volume of $500 \mu \mathrm{l}$ buffer for $4 \mathrm{~h}$ at $37^{\circ} \mathrm{C}$ in an incubator at $90 \%$ humidity and $5 \% \mathrm{CO}_{2}$. Following dialysis, tissues and buffer samples were analyzed as described for the plasma protein binding studies.

Pharmacokinetic Studies in Mice. Twelve female CD-1 mice (Charles River Laboratories, Hollister, CA) were given an oral (PO) dose of the indicated compound in $0.5 \%$ methylcellulose $/ 0.2 \%$ Tween 80 (MCT). Two blood samples of approximately $0.15 \mathrm{~mL}$ were collected from each mouse ( $\mathrm{n}=3$ mice per timepoint) by retro-orbital bleed or terminal cardiac puncture while the animals were anesthetized with isoflurane. Blood samples were collected in tubes containing K2EDTA as the anticoagulant, predose and at 0.083, 0.25, 0.5, 1, 3, 6, 9, and 24 $\mathrm{h}$ post-dose. Samples were centrifuged within $1 \mathrm{~h}$ of collection and plasma was collected and stored at $-80^{\circ} \mathrm{C}$ until analysis. Total concentrations of the compound were determined by liquid chromatography-tandem mass spectrometry (LC-MS/MS), following plasma protein precipitation with acetonitrile, and injection of the supernatant onto the column, a Varian MetaSil AQ C18 column $(50 \times 2 \mathrm{~mm}, 5 \mu \mathrm{m}$ particle size $)$. A CTC HTS PAL autosampler (LEAP Technologies, Chapel Hill, NC) linked to a Shimadzu SCL-10A controller with LC-10AD pumps (Shimadzu, Columbia MD), coupled with an AB Sciex API 4000 triple quadrupole mass spectrometer (AB Sciex, Foster City, CA) were used for the LC-MS/MS assay. The aqueous mobile phase was water with $0.1 \%$ formic acid and the organic mobile phase was acetonitrile with $0.1 \%$ formic acid. The lower and upper limits of quantitation of the assay were $0.005 \mu \mathrm{M}$ and $10 \mu \mathrm{M}$, respectively. The total run time was $1.5 \mathrm{~min}$ and the ionization was conducted in the 
positive ion mode. Where brain concentration was determined, brains were collected at 1 and $6 \mathrm{~h}$ post-dose from 3 different animals at each time point, rinsed with ice-cold saline, weighed and stored at $-80^{\circ} \mathrm{C}$ until analysis. For compound quantitation, mouse brains were homogenized in 3 volumes of water. The homogenates were extracted by protein precipitation with acetonitrile. LC-MS/MS analysis was conducted as described for the plasma. Brain homogenate concentrations were converted to brain concentrations for the calculations of brain-to-plasma ratios.

Modulation of pAKT in Brain. Female CD-1 mice were administered a single PO dose of the indicated compound. Brains and plasma were collected at the indicated time post-dose, from 3 animals at each time point. Individual brains were split in half for PD analysis and compound concentration measurement. The samples were stored at $-70^{\circ} \mathrm{C}$ and analyzed for total concentration. For PD analysis, cell extraction buffer (Invitrogen, Camarillo, CA) containing 10 $\mathrm{mM}$ Tris pH 7.4, $100 \mathrm{mM} \mathrm{NaCl}, 1 \mathrm{mM}$ EDTA, $1 \mathrm{mM}$ EGTA, $1 \mathrm{mM} \mathrm{NaF}, 20 \mathrm{mM} \mathrm{Na}_{4} \mathrm{P}_{2} \mathrm{O}_{7}, 2$ $\mathrm{mM} \mathrm{Na} \mathrm{VO}_{4}, 1 \%$ Triton X-100, $10 \%$ glycerol, $0.1 \%$ SDS, and $0.5 \%$ deoxycholate was supplemented with phosphatase, protease inhibitors (Sigma, St. Louis, MO) and 1mM PMSF and added to frozen brain biopsies. Brains were homogenized with a small pestle (Konte Glass Company, Vineland, NJ), sonicated briefly on ice, and centrifuged at $20,000 \mathrm{~g}$ for $20 \mathrm{~min}$ at $4^{\circ} \mathrm{C}$. Protein concentration was determined using BCA protein assay (Pierce, Rockford, IL). Proteins were separated by electrophoresis and transferred to NuPage nitrocellulose membranes (Invitrogen, Camarillo, CA). Licor Odyssey Infrared detection system (Licor, Lincoln, NE) was used to assess and quantify protein expression. PI3K pathway markers were evaluated by immunoblotting using antibodies against $\mathrm{pAkt}^{\mathrm{ser} 473}$ and total Akt (Invitrogen, Camarillo, CA and 
Cell Signaling, Danvers, MA). Inhibition of pAkt (\%) was calculated by comparing pAkt signal with that measured in untreated mice.

In Vivo Xenograft Studies. All in vivo studies were conducted in compliance with Genentech's Institutional Animal Care and Use Committee. PTEN-null U-87 MG/M human glioblastoma cancer cells (an in-house derivative of U-87 MG cells from American Type Culture Collection (Manassas, VA)) were cultured in RPMI 1640 media plus 1\% L-glutamine with $10 \%$ fetal bovine serum (HyClone; Waltham, MA). Cells in log-phase growth were harvested and resuspended in HBSS:Matrigel (BD Biosciences; Franklin Lakes, NJ) (1:1, v:v) for injection into female NCr nude mice (Taconic Farms, Cambridge City, IN) aged 20 weeks. Animals received five million cells subcutaneously in the right lateral thorax in $0.1 \mathrm{~mL}$. Mice bearing established tumors in the range of $200-500 \mathrm{~mm}^{3}$ were separated into groups of equally sized tumors $(\mathrm{n}=6$ 7/group) to receive escalating doses of $\mathbf{1 6}$. The inhibitor was formulated once weekly in $0.5 \%$ methylcellulose and $0.2 \%$ Tween- 80 at concentrations needed for target doses in a volume of 0.2 $\mathrm{mL}$. All formulations were stored in a refrigerator and brought to room temperature and mixed well by vortex before oral administration by gavage once daily for 23 days. Tumor volumes were calculated from perpendicular length and width caliper measurements using the formula: Tumor Volume $\left(\mathrm{mm}^{3}\right)=0.5 \mathrm{X}\left(\right.$ Length $\left.\mathrm{X} \mathrm{Width}^{2}\right)$. Changes in body weights are reported as a percentage change from the starting weight.

A mixed modeling approach was used to analyze the repeated measurement of tumor volumes from the same animals over time since this approach addresses both repeated measurements as well as modest dropouts before study end (Pinheiro et al. 2008). Log2(tumor volume) growth traces were fitted to each dose group with restricted cubic splines for the dose and fixed time effects. Fitting was done via a linear mixed-effects model, using the R package nlme (version 
3.1-97) in $\mathrm{R}$ version 2.13.0 ( $\mathrm{R}$ Development Core Team 2008; R Foundation for Statistical Computing; Vienna, Austria). Fitted tumor volumes were plotted in the natural scale in Prism (version 5.0b for Mac) (GraphPad Software; La Jolla, CA). Linear mixed-effects analysis was also employed using $\mathrm{R}$ to analyze the repeated measurement of body weight changes from the same animals over time.

\section{Chemistry}

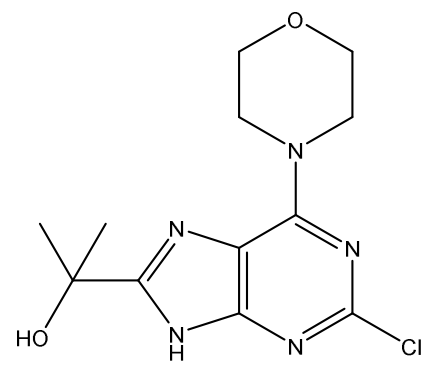

\section{2-(2-chloro-6-morpholino-9H-purin-8-yl)propan-2-ol (12).}

4-(2-chloro-9-(tetrahydro-2H-pyran-2-yl)-9H-purin-6-yl)morpholine ${ }^{3}$ (10, 25.0 g, 0.08 mol) was cooled to $-78^{\circ} \mathrm{C}$ in THF $(400 \mathrm{~mL})$. A solution of $n$-butyllithium $(2.5 \mathrm{M}$ in hexanes, $62 \mathrm{~mL}, 0.15$ mol) was added portion-wise over $10 \mathrm{~min}$. The mixture gradually turned yellow. The reaction mixture stirred at $-78^{\circ} \mathrm{C}$ for $15 \mathrm{~min}$, then anhydrous acetone $(12.5 \mathrm{~mL}, 0.17 \mathrm{~mol})$ was added. The resulting reaction mixture was slowly warmed to $0^{\circ} \mathrm{C}$ over a 2 hour period. The mixture was subsequently quenched with water, extracted with EtOAc and dried over $\mathrm{MgSO}_{4}$. The slurry was filtered and concentrated in vacuo to provide 2-(2-chloro-6-morpholino-9-(tetrahydro-2H-pyran2-yl)-9H-purin-8-yl)propan-2-ol. The crude material was taken up in $\mathrm{MeOH}(530 \mathrm{~mL})$ and ptoluenesulfonic acid $(1.3 \mathrm{~g}, 0.008 \mathrm{~mol})$ was added. The reaction mixture was heated to $50^{\circ} \mathrm{C}$ for $30 \mathrm{~min}$. The reaction mixture was concentrated, rinsed with excess water and filtered to dryness to provide 12 ( $21.6 \mathrm{~g}, 94 \%$ over 2 steps).

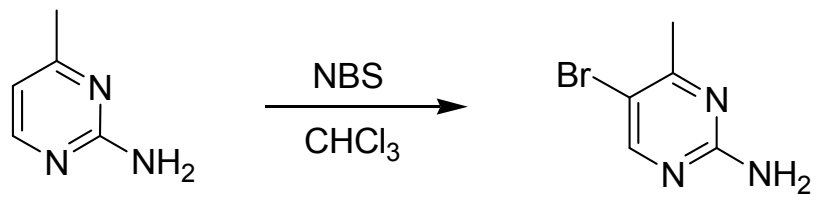




\section{4-methyl-5-(4, 4, 5, 5-tetramethyl (1, 3, 2-dioxaborolan-2-yl)) pyrimidine-2-ylamine (17).}

To a solution of 4-methylpyrimidine-2-ylamine $(8.0 \mathrm{~g}, 0.073 \mathrm{~mol})$ in chloroform $(320 \mathrm{~mL})$ was added N-bromosuccinimide $(13.7 \mathrm{~g}, 0.077 \mathrm{~mol})$. The reaction mixture was stirred in the dark for $18 \mathrm{hrs}$. LC/MS indicated the reaction was completed. The mixture was diluted with DCM, then washed with $1 \mathrm{~N} \mathrm{NaOH}$ aq solution and brine, dried over $\mathrm{MgSO}_{4}$, filtered and concentrated to yield 5-bromo-4-methylpyrimidine-2-ylamin (12 g, Yield: 86\%).
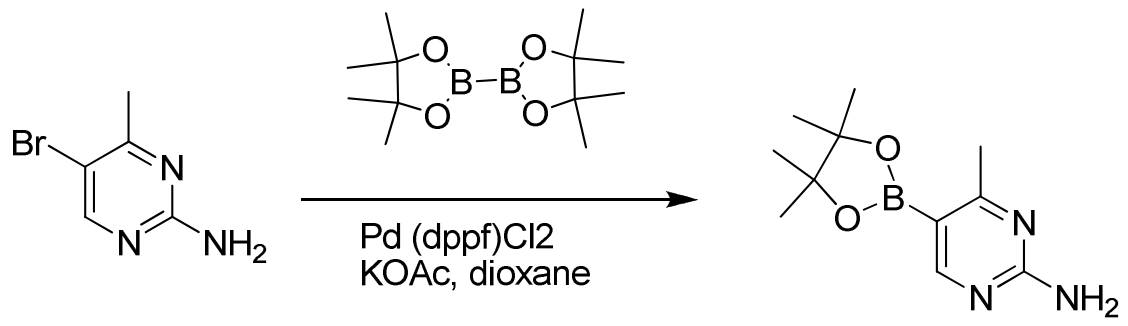

\section{4-methyl-5-(4,4,5,5-tetramethyl-1,3,2-dioxaborolan-2-yl)pyrimidin-2-amine (18).}

A mixture of 5-bromo-4-methylpyrimidine-2-ylamine $(5.0 \mathrm{~g}, 26 \mathrm{mmol})$, potassium acetate $(7.83$

g, $79.8 \mathrm{mmol})$, 4,4,5,5-tetramethyl-2-(4,4,5,5-tetramethyl-1,3,2-dioxaborolan-2-yl)- 1,3,2dioxaborolane (7.43 g, $29.2 \mathrm{mmol})$ in dioxane $(140 \mathrm{~mL})$ was stirred for $20 \mathrm{~min}$ under nitrogen. 1,1'-bis(diphenylphosphino)ferrocene palladium (II) chloride dichloromethane adduct (1.08 g, $1.33 \mathrm{mmol}$ ) was added to the reaction mixture. The reaction mixture was heated to $115^{\circ} \mathrm{C}$ for 18 $\mathrm{h}$ under nitrogen. Upon completion, the mixture was cooled and EtOAc was added. The resulting mixture was sonicated and filtered. Additional EtOAc was used to wash the solid. The combined organic extracts were washed with water, dried over $\mathrm{MgSO}_{4}$, filtered and concentrated. The crude was purified by chromatography eluting with $20 \sim 100 \%$ EtOAc/hexane to yield $4.5 \mathrm{~g}$ of 4-methyl-5-(4,4,5,5-tetramethyl (1,3,2-dioxaborolan-2-yl))pyrimidine-2-ylamine (yield: 74\%). ${ }^{1} \mathrm{H}$ NMR (DMSO, $400 \mathrm{MHz}$ ): $\delta 8.28$ (s, 1H), 6.86 (br s, 2H), 2.35 (s, $\left.3 \mathrm{H}\right), 1.25$ (s, $12 \mathrm{H}) . \mathrm{MS}(\mathrm{ESI}) \mathrm{m} / \mathrm{e}\left(\mathrm{M}+\mathrm{H}^{+}\right) 236.15,154.07$. 


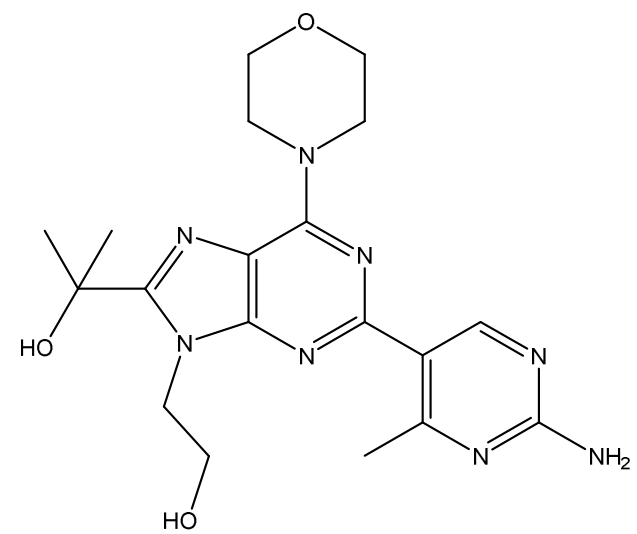

2-(2-(2-amino-4-methylpyrimidin-5-yl)-9-(2-hydroxyethyl)-6-morpholino-9H-purin-8yl)propan-2-ol (4).

2-(2-chloro-6-morpholino-9H-purin-8-yl)propan-2-ol (12, $10 \mathrm{~g}, 0.03 \mathrm{~mol})$ was dissolved in DMF $(20 \mathrm{~mL})$. 2-Bromoethyl acetate $(11.1 \mathrm{~mL}, 0.1 \mathrm{~mol})$ and cesium carbonate $(21.9 \mathrm{~g}, 0.07 \mathrm{~mol})$ were added and the reaction mixture was heated to $50{ }^{\circ} \mathrm{C}$ for several hours. After quenching with water, the reaction mixture was extracted with EtOAc and concentrated. The crude reaction mixture was purified by silica gel chromatography (gradient of 0-50\% EtOAc in hexane). The resulting 2-(2-chloro-8-(2-hydroxypropan-2-yl)-6-morpholino-9H-purin-9-yl)ethyl acetate was treated with 4-methyl-5-(4,4,5,5-tetramethyl-1,3,2-dioxaborolan-2-yl)pyrimidin-2-amine (18, $14.5 \mathrm{~g}, 0.07 \mathrm{~mol})$ and $\mathrm{PdCl}_{2} \mathrm{Ph}_{2}(1.8 \mathrm{~g}, 2.5 \mathrm{mmol})$ in $1 \mathrm{M} \mathrm{Na}_{2} \mathrm{CO}_{3}(100 \mathrm{~mL})$ and $\mathrm{CH}_{3} \mathrm{CN}(100$ $\mathrm{mL}$ ). The reaction mixture was divided into 10 equal batches and each was microwaved at 300 watts, $140{ }^{\circ} \mathrm{C}$ for $15 \mathrm{~min}$. All batches were then combined and concentrated then taken up into $\mathrm{iPrOH}(20 \mathrm{~mL})$ and heated to reflux. After then cooling to RT the resulting solid was filtered to provide 2-(2-(2-amino-4-methylpyrimidin-5-yl)-9-(2-hydroxyethyl)-6-morpholino-9H-purin-8yl)propan-2-ol (4, 4.6 g, 37\% over 2 steps). ${ }^{1} \mathrm{H}$ NMR (400 MHz, DMSO) $\delta 8.82$ (s, 1H), 6.79 (s, 2H), $5.66(\mathrm{~s}, 1 \mathrm{H}), 5.02(\mathrm{~s}, 1 \mathrm{H}), 4.57(\mathrm{t}, J=6.8 \mathrm{~Hz}, 2 \mathrm{H}), 4.21(\mathrm{~s}, 4 \mathrm{H}), 3.84(\mathrm{~d}, J=3.6 \mathrm{~Hz}, 2 \mathrm{H})$, $3.78-3.66$ (m, 4H), 2.65 (s, 3H), 1.62 (s, 6H). ${ }^{13} \mathrm{C}$ NMR (100 MHz, DMSO) $\delta 166.71,162.99$, $160.11,156.87,155.62,153.81,153.06,121.29,116.09,70.42,66.69,59.68,46.57,45.75,30.62$, 25.13. HRMS (ESI): m/z calcd: $\mathrm{C}_{19} \mathrm{H}_{27} \mathrm{O}_{3} \mathrm{~N}_{8}=415.2201$; found: 415.2176 . 
<smiles>Cn1cnc2c(N3CCOCC3)nc(-c3cnc(N)nc3)nc21</smiles>

\section{5-(9-methyl-6-morpholino-9H-purin-2-yl)pyrimidin-2-amine (5).}

2-chloro-9-methyl-6-morpholin-4-yl-9H-purine ${ }^{3}$ (0.20 mg, $\left.0.79 \mathrm{mmol}\right)$, 2-aminopyrimidine-5boronic acid, pinacol ester (227 mg, $1.02 \mathrm{mmol})$, tetrakis(triphenylphosphine)palladium(0) (46 $\mathrm{mg}, 0.039 \mathrm{mmol}), 1.0 \mathrm{M}$ of $\mathrm{Na}_{2} \mathrm{CO}_{3}$ in water $(1.5 \mathrm{~mL})$, and acetonitrile $(1.9 \mathrm{~mL})$ were combined and the reaction mixture was heated in the microwave at $140{ }^{\circ} \mathrm{C}$ for $15 \mathrm{~min}$. The reaction mixture was concentrated in vacuo and submitted for purification via reverse phase chromatography to afford the title compound as a solid (91 mg, 37\%). ${ }^{1} \mathrm{H}$ NMR (400 MHz, DMSO) $\delta 9.12$ (s, 2H), $8.11(\mathrm{~s}, 1 \mathrm{H}), 7.03$ (s, 2H), 3.77 (s, 3H), $3.76-3.73(\mathrm{~m}, 4 \mathrm{H}), 3.32$ (s, 4H). ${ }^{13} \mathrm{C} \mathrm{NMR}(100 \mathrm{MHz}$, DMSO) $\delta 164.39,158.22,155.20,153.42,152.27,141.15,120.89,118.25,66.71,45.63,29.85$. HRMS (ESI): m/z calcd: $\mathrm{C}_{14} \mathrm{H}_{17} \mathrm{ON}_{8}=313.1520$; found: 313.1500 .<smiles>Cn1c(I)nc2c(N3CCOCC3)nc(Cl)nc21</smiles>

\section{4-(2-chloro-8-iodo-9-methyl-9H-purin-6-yl)morpholine (19).}

A suspension of 2-chloro-9-methyl-6-morpholin-4-yl-9H-purine (2.95 g, $11.7 \mathrm{mmol})$ and TMEDA (2.6 mL, $2.03 \mathrm{~g}, 17.5 \mathrm{mmol})$ in THF $(80 \mathrm{~mL})$ was cooled to $-78^{\circ} \mathrm{C}$ before the drop wise addition of $n$-BuLi $(9.8 \mathrm{~mL}, 24.5 \mathrm{mmol}, 2.5 \mathrm{M}$ solution in hexanes). The resulting mixture was warmed to $-40{ }^{\circ} \mathrm{C}$ and stirred 40 mins. The mixture was cooled back to $-78{ }^{\circ} \mathrm{C}$ before the addition of 1-chloro-2-iodoethane $(3.7 \mathrm{~mL}, 7.8 \mathrm{~g}, 40.8 \mathrm{mmol})$. The resulting mixture was allowed to warm to r.t. over a $2 \mathrm{~h}$ period then quenched with $\mathrm{NH}_{4} \mathrm{Cl}$ and extracted with EtOAc 
$(\times 4)$. The combined organics were dried $\left(\mathrm{Na}_{2} \mathrm{SO}_{4}\right)$ and concentrated in vacuo affording the title compound as a yellow solid (4.02 g, 91\%). LCMS: $\mathrm{R}_{\mathrm{T}} 4.09 \mathrm{~min}, \mathrm{~m} / \mathrm{z}=379.9[\mathrm{M}+\mathrm{H}]^{+}$.<smiles>CCc1nc2c(N3CCOCC3)nc(Cl)nc2n1C</smiles>

\section{4-(2-chloro-8-ethyl-9-methyl-9H-purin-6-yl)morpholine (20).}

4-(2-chloro-8-iodo-9-methyl-9H-purin-6-yl)morpholine (19, $0.20 \mathrm{~g}, 0.53 \mathrm{mmol})$ and 1,1'bis(diphenylphosphino)ferrocene palladium(II) chloride $(6.5 \mathrm{mg}, 0.008 \mathrm{mmol})$ were dissolved in 1,4-dioxane (2.634 mL). 1.0 M of diethyl zinc in hexane (1.1 mL, $1.1 \mathrm{mmol})$ was added drop wise to the reaction mixture. The reaction was stirred at $60{ }^{\circ} \mathrm{C}$ for $2.5 \mathrm{~h}$, then cooled to ambient temperature. $\mathrm{MeOH}$ was then added drop wise, and the volatiles removed in vacuo. The crude residue was diluted with $1 \mathrm{~N} \mathrm{HCl,} \mathrm{water,} \mathrm{brine} \mathrm{and} \mathrm{EtOAc.} \mathrm{The} \mathrm{layers} \mathrm{were} \mathrm{separated} \mathrm{and} \mathrm{the}$ aqueous phase was extracted into EtOAc $(\times 3)$, dried over $\mathrm{Na}_{2} \mathrm{SO}_{4}$, filtered and absorbed onto Celite for purification by flash column chromatography [12 g column, 0-80\% EtOAc/heptanes over $18 \mathrm{~min}$ ] to afford the title compound as a light yellow solid (106 mg, 72\%).<smiles>CCc1nc2c(N3CCOCC3)nc(-c3cnc(N)nc3)nc2n1C</smiles>

\section{5-(8-ethyl-9-methyl-6-morpholino-9H-purin-2-yl)pyrimidin-2-amine (6).}

A similar coupling procedure described for the synthesis of 5-(9-methyl-6-morpholino-9H-purin2-yl)pyrimidin-2-amine (5) above, using 20 and 2-aminopyrimidine-5-boronic acid pinacol ester, was used to generate this compound. 
${ }^{1} \mathrm{H}$ NMR (400 MHz, DMSO) $\delta 9.11$ (s, 2H), 7.00 (s, 2H), 4.24 (s, 4H), 3.77-3.72 (m, 4H), 3.71$3.69(\mathrm{~m}, 3 \mathrm{H}), 2.85$ (q, $J=7.5 \mathrm{~Hz}, 2 \mathrm{H}), 1.29(\mathrm{t}, J=7.5 \mathrm{~Hz}, 3 \mathrm{H}) .{ }^{13} \mathrm{C}$ NMR (100 MHz, DMSO) $\delta$ $164.31,158.08,154.31,153.26,153.03,152.99,152.68,121.03,117.44,66.73,45.65,28.60$, 20.60, 11.53. HRMS (ESI): m/z calcd: $\mathrm{C}_{16} \mathrm{H}_{21} \mathrm{ON}_{8}=341.1833$; found: 341.1811 .<smiles>Cn1c(C2CCC2)nc2c(N3CCOCC3)nc(Cl)nc21</smiles>

4-(2-chloro-8-cyclobutyl-9-methyl-9H-purin-6-yl)morpholine (21).

4-(2-chloro-8-iodo-9-methyl-9H-purin-6-yl)morpholine (0.5 g, $1.32 \mathrm{mmol}$ ), potassium cyclobutyltrifluoroborate $(320 \mathrm{mg}, 1.98 \mathrm{mmol}), \mathrm{Cs}_{2} \mathrm{CO}_{3}(1.3 \mathrm{~g}, 3.95 \mathrm{mmol})$, and $\mathrm{Pd}(\mathrm{OAc})_{2}(6$ $\mathrm{mg}, 0.03 \mathrm{mmol})$ were suspended in toluene $(4.8 \mathrm{~mL})$ and heated at $100{ }^{\circ} \mathrm{C}$ overnight. The reaction mixture was cooled to ambient temperature and diluted with saturated aqueous sodium bicarbonate, water, brine and EtOAc. The layers were separated and the aqueous phase was extracted into EtOAc (3x), dried over $\mathrm{Na}_{2} \mathrm{SO}_{4}$, filtered and absorbed onto Celite for purification via FCC [80 g, 0-50\% EtOAc/heptanes] to afford $64 \mathrm{mg}(16 \%)$ of the title compound.<smiles>Cn1c(C2CCC2)nc2c(N3CCOCC3)nc(-c3cnc(N)nc3)nc21</smiles>

\section{5-(8-cyclobutyl-9-methyl-6-morpholino-9H-purin-2-yl)pyrimidin-2-amine (7).}

A similar coupling procedure described for the synthesis of 5-(9-methyl-6-morpholino-9H-purin2-yl)pyrimidin-2-amine (5) above, using 21 and 2-aminopyrimidine-5-boronic acid pinacol ester, was used was used to generate this compound. ${ }^{1} \mathrm{H}$ NMR (400 MHz, DMSO) $\delta 9.11(\mathrm{~s}, 2 \mathrm{H}), 7.00$ $(\mathrm{s}, 2 \mathrm{H}), 4.27(\mathrm{~s}, 4 \mathrm{H}), 3.90-3.79(\mathrm{~m}, 1 \mathrm{H}), 3.79-3.71(\mathrm{~m}, 4 \mathrm{H}), 3.62(\mathrm{~s}, 3 \mathrm{H}), 2.43-2.34(\mathrm{~m}, 4 \mathrm{H})$, $2.16-2.01(\mathrm{~m}, 1 \mathrm{H}), 1.96-1.85(\mathrm{~m}, 1 \mathrm{H}) .{ }^{13} \mathrm{C}$ NMR (100 MHz, DMSO) $\delta 164.31,158.09$, 
154.37, 154.19, 153.42, 152.77, 121.03, 117.40, 66.74, 45.65, 31.95, 28.52, 26.50, 18.48. HRMS (ESI): $\mathrm{m} / \mathrm{z}$ calcd: $\mathrm{C}_{18} \mathrm{H}_{23} \mathrm{ON}_{8}=367.1989$; found: 367.1967 .<smiles>Cn1c(C2(O)COC2)nc2c(N3CCOCC3)nc(Cl)nc21</smiles>

\section{3-(2-chloro-9-methyl-6-morpholino-9H-purin-8-yl)oxetan-3-ol (22).}

To 4-(2-chloro-9-methyl-9H-purin-6-yl)morpholine $(1.50 \mathrm{~g}, 5.93 \mathrm{mmol})$ in THF $(48 \mathrm{~mL})$ at -48 ${ }^{\circ} \mathrm{C}$ was added $2.5 \mathrm{M}$ of $n$-butyllithium in hexanes $(6.6 \mathrm{~mL}, 16.6 \mathrm{mmol})$ and stirred for $30 \mathrm{~min}$. Following this, 3-oxetanone $(1.1 \mathrm{~mL}, 23.7 \mathrm{mmol})$ was added and the reaction mixture was stirred for $2 \mathrm{~h}$. The mixture was quenched with water and extracted with EtOAc. The combined organics were dried over $\mathrm{Na}_{2} \mathrm{SO}_{4}$, filtered and absorbed onto Celite for purification via FCC [80g, $0-100 \%$ EtOAc in heptanes] to afford the title compound as a white solid (1.32 g, 68\%).<smiles>Cn1c(C2(O)COC2)nc2c(N3CCOCC3)nc(-c3cnc(N)nc3)nc21</smiles>

\section{3-(2-(2-aminopyrimidin-5-yl)-9-methyl-6-morpholino-9H-purin-8-yl)oxetan-3-ol (8).}

A similar coupling procedure described for the synthesis of 5-(9-methyl-6-morpholino-9H-purin2-yl)pyrimidin-2-amine (5) above, using 22 and 2-aminopyrimidine-5-boronic acid pinacol ester, was used was used to generate this compound.

${ }^{1} \mathrm{H}$ NMR (400 MHz, DMSO) $\delta 9.13$ (d, $\left.J=5.1 \mathrm{~Hz}, 2 \mathrm{H}\right), 7.05$ (s, 2H), 6.90 (s, 1H), 4.97 (dd, $J=$ 149.7, $6.8 \mathrm{~Hz}, 4 \mathrm{H}$ ), 4.28 (s, 4H), $3.84-3.73$ (m, 4H), 3.68 (s, 3H). ${ }^{13} \mathrm{C}$ NMR (100 MHz, DMSO) $\delta 164.42,164.39,158.27,158.23,155.33,155.30,153.95,153.91,153.34,153.31,150.45$, 
150.43, 120.84, 120.80, 116.55, 81.43, 71.41, 66.76, 45.72, 29.70. HRMS (ESI): $\mathrm{m} / \mathrm{z}$ calcd: $\mathrm{C}_{17} \mathrm{H}_{21} \mathrm{O}_{3} \mathrm{~N}_{8}=385.173$; found: 385.1710 .<smiles>COC1(c2nc3c(N4CCOCC4)nc(Cl)nc3n2C)COC1</smiles>

\section{4-(2-chloro-8-(3-methoxyoxetan-3-yl)-9-methyl-9H-purin-6-yl)morpholine (23).}

A solution of 3-(2-chloro-9-methyl-6-morpholino-9H-purin-8-yl)oxetan-3-ol (0.5 g, 1.54 mmol) in DMF $(8.3 \mathrm{~mL})$ was cooled to $0{ }^{\circ} \mathrm{C}$. $\mathrm{NaH}(60 \%$ dispersion in oil, $185 \mathrm{mg}, 7.70 \mathrm{mmol})$ was added in one portion. The reaction mixture was stirred for 5 minutes and resulted in a dark orange hue. Methyl iodide $(0.29 \mathrm{~mL}, 4.62 \mathrm{mmol})$ was added and the reaction mixture was allowed to warm to ambient temperature and stirred $2 \mathrm{~h}$. The reaction was diluted with saturated aqueous $\mathrm{Na}_{2} \mathrm{CO}_{3}$ solution and extracted into EtOAc. The combined organics were dried over $\mathrm{Na}_{2} \mathrm{SO}_{4}$, filtered and absorbed onto Celite for purification via FCC (80 g column, $0-100 \%$ EtOAc in heptane) to afford the title compound as a white solid (505 mg, 96\%).<smiles>COC1(c2nc3c(N4CCOCC4)nc(-c4cnc(N)nc4)nc3n2C)COC1</smiles>

5-(8-(3-methoxyoxetan-3-yl)-9-methyl-6-morpholino-9H-purin-2-yl)pyrimidin-2-amine (9).

A similar coupling procedure described for the synthesis of 5-(9-methyl-6-morpholino-9H-purin2-yl)pyrimidin-2-amine (5) above, using $\mathbf{2 3}$ and 2-aminopyrimidine-5-boronic acid pinacol ester, was used was used to generate this compound.

${ }^{1} \mathrm{H}$ NMR (400 MHz, DMSO) $\delta 9.14$ (s, 2H), $7.06(\mathrm{~s}, 2 \mathrm{H}), 5.12(\mathrm{~d}, J=7.1 \mathrm{~Hz}, 2 \mathrm{H}), 4.84$ (d, $J=$ $7.1 \mathrm{~Hz}, 2 \mathrm{H}), 4.29$ (s, 4H), 3.80-3.74 (m, 4H), 3.64 (s, 3H), 3.04 (s, 3H). ${ }^{13} \mathrm{C}$ NMR (100 MHz, 
DMSO) $\delta 164.48,164.45,158.30,155.57,154.00,153.35,147.38,120.75,116.98,77.74,77.27$, 66.71, 52.28, 29.43. HRMS (ESI): $\mathrm{m} / \mathrm{z}$ calcd: $\mathrm{C}_{18} \mathrm{H}_{23} \mathrm{O}_{3} \mathrm{~N}_{8}=399.1888$; found: 399.1866.

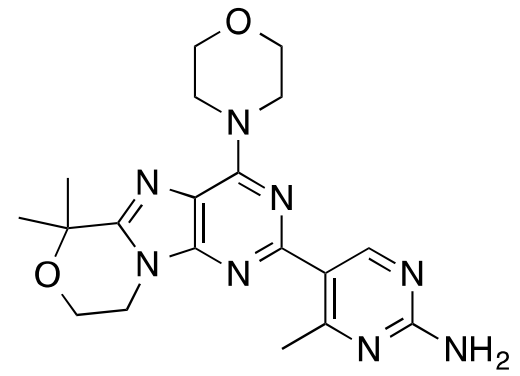

\section{5-(6,6-dimethyl-4-morpholino-8,9-dihydro-6H-[1,4]oxazino[4,3-e]purin-2-yl)-4- methylpyrimidin-2-amine (15).}

A mixture of 2-(2-(2-amino-4-methylpyrimidin-5-yl)-9-(2-hydroxyethyl)-6-morpholino-9Hpurin-8-yl)propan-2-ol $(4,550 \mathrm{mg}, 1.3 \mathrm{mmol})$ and TFA $(0.36 \mathrm{~mL}, 4.7 \mathrm{mmol})$ in toluene $(9 \mathrm{~mL})$ was heated at $110^{\circ} \mathrm{C}$ and stirred $4 \mathrm{~h}$. The reaction mixture was cooled to room temperature and concentrated in vacuo. Analytical LC-MS indicated conversion to the cyclic product as well as the E2 by-product, 2-(2-(2-amino-4-methylpyrimidin-5-yl)-6-morpholino-8-(prop-1-en-2-yl)-9Hpurin-9-yl)ethanol. The crude residue was dissolved in DMF $(1 \mathrm{~mL})$ and purified by preparative rp-HPLC. This provided $302 \mathrm{mg}$ (57\% yield) of $15 .{ }^{1} \mathrm{H}$ NMR (400 MHz, DMSO) $\delta 8.79(\mathrm{~s}, 1 \mathrm{H})$, 6.79 (s, 2H), 4.27 (d, J=53.4 Hz, 4H), 4.12 (s, 5H), $3.81-3.66(\mathrm{~m}, 5 \mathrm{H}), 2.71-2.58(\mathrm{~m}, 3 \mathrm{H})$, $1.58(\mathrm{~s}, 6 \mathrm{H}) .{ }^{13} \mathrm{C}$ NMR $(100 \mathrm{MHz}$, DMSO) $\delta 166.70,162.98,159.99,156.87,152.93,151.73$, 121.19, 117.21, 74.17, 66.66, 58.28, 45.76, 41.93, 27.81, 25.01. HRMS (ESI): m/z calcd: $\mathrm{C}_{19} \mathrm{H}_{25} \mathrm{O}_{2} \mathrm{~N}_{8}=397.2095$; found: 397.2074 .

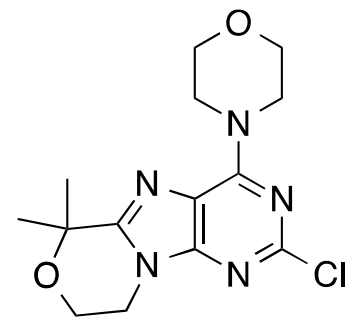

\section{2-chloro-6,6-dimethyl-4-morpholino-8,9-dihydro-6H-[1,4] oxazino[4,3-e]purine (13)}

2-(2-chloro-6-morpholino-9H-purin-8-yl)propan-2-ol (12, ca. 15.0 g, 50.4 mmol) was treated with 1,2-dibromoethane $(8.7 \mathrm{~mL}, 100 \mathrm{mmol})$ and cesium carbonate $(41.0 \mathrm{~g}, 126 \mathrm{mmol})$ in DMF 
(200 mL). The reaction mixture was heated at $90{ }^{\circ} \mathrm{C}$ for $1.5 \mathrm{~h}$. LC-MS indicated complete conversion to the cyclic product with $\sim 10 \%$ of E2 elimination product present. The reaction mixture was cooled to room temperature and poured into a separatory funnel containing $1 \mathrm{~N} \mathrm{HCl}$ and EtOAc (50:50). The aqueous layer was extracted several times with EtOAc and the combined organic portions were washed once with water. Subsequent drying over $\mathrm{MgSO}_{4}$ was followed by filtration and concentration to yield a crude oily residue. This material was loaded onto a $300 \mathrm{~g}$ ISCO column and purified by slow gradient flash column chromatography (15-30\% EtOAc in heptane). Fractions containing the desired product were concentrated and dried down under high vacuum pressure for an overnight period to give $14.3 \mathrm{~g}$ (88\% yield) of 2-chloro-6,6dimethyl-4-morpholino-8,9-dihydro-6H-[1,4]oxazino[3,4-e]purine (13). MS (ESI+): m/z 324.2 $\left(\mathrm{M}+\mathrm{H}^{+}\right) .{ }^{1} \mathrm{H}$ NMR $(400 \mathrm{MHz}, \mathrm{DMSO}) \delta 4.07$ (m, 8H), $3.72(\mathrm{~m}, 4 \mathrm{H}), 1.57$ (s, 6H).

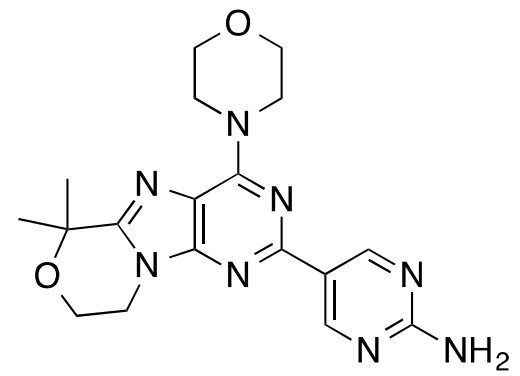

\section{5-(6,6-dimethyl-4-morpholino-8,9-dihydro-6H-[1,4]oxazino[4,3-e]purin-2-yl)pyrimidin-2- amine (16).}

2-Chloro-6,6-dimethyl-4-morpholino-8,9-dihydro-6H-[1,4]oxazino[3,4-e]purine (180 mg, 0.56 $\mathrm{mmol})$ in 1,2-dimethoxyethane $(5.1 \mathrm{~mL})$ was added 5-(4,4,5,5-tetramethyl-1,3,2-dioxaborolan-2yl)pyrimidin-2-amine (180 mg, $0.83 \mathrm{mmol})$ and $1.0 \mathrm{M}$ of cesium carbonate in water $(1.7 \mathrm{~mL})$. The reaction mixture was degassed for 5 min and recycled with nitrogen atmosphere. Subsequently, 1,1'-bis(diphenylphosphino)ferrocene palladium(II) chloride (54 mg, $0.067 \mathrm{mmol}$ ) was added, and the mixture was degassed and recycled again. The reaction vial was then subjected to microwave irradiation for 20 mins at $140{ }^{\circ} \mathrm{C}$. Solid precipitate that formed during the reaction was filtered and rinsed with excess water. The precipitate was taken up in DCM and purified by FCC ( $40 \mathrm{~g}$ column, $0.5-4 \% \mathrm{MeOH}$ in DCM, slow gradient) to isolate $\mathbf{1 6}$ as a tancolored solid (56 mg, 27\% yield). ${ }^{1} \mathrm{H}$ NMR (400 MHz, DMSO) $\delta 9.10$ (s, 2H), 7.03 (s, 2H), 4.23 (s, 4H), $4.17-4.02(\mathrm{~m}, 4 \mathrm{H}), 3.86-3.68(\mathrm{~m}, 4 \mathrm{H}), 1.58(\mathrm{~s}, 6 \mathrm{H}) .{ }^{13} \mathrm{C}$ NMR $(100 \mathrm{MHz}, \mathrm{DMSO}) \delta$ 
$164.35,158.12,154.66,153.00,151.82,151.50,120.86,117.77,74.17,66.70,58.31,45.63$, 41.96, 27.81. HRMS (ESI): m/z calcd: $\mathrm{C}_{18} \mathrm{H}_{23} \mathrm{O}_{2} \mathrm{~N}_{8}=383.1938$; found: 383.1914 .

${ }^{1}$ Experimental details for the Class I PI3K assays used were identical to that previously reported: Heffron, T. P.; Heald, R.; Ndubaku, C.; Wei, B. Q.; Augistin, M.; Do, S.; Edgar, K.; Eigenbrot, C.; Friedman, L.; Gancia, E.; Jackson, P. S.; Jones, G.; Kolesnikov, A.; Lee, L.; B.; Lesnick, J. D.; Lewis, C.; McLean, N.; Mörtle, M.; Nonomiya, J.; Pang, J.; Price, S.; Prior, W. W.; Salphati, L.; Sideris, S.; Staben, S. T.; Steinbacher, S.; Tsui, V.; Wallin, J.; Sampath, D.; Olivero, A. G.; "The Rational Design of Selective Inhibitors of Phosphoinositide 3-Kinase Culminating in the Identification of Clinical Candidate GDC-0326.” J. Med. Chem. 2016, ASAP, DOI: 10.1021/acs.jmedchem.5b01483

${ }^{2}$ Kalvass, J. C.; Maurer, T. S.; Pollack, G. M. Use of plasma and brain unbound fractions to assess the extent of brain distribution of 34 drugs: comparison of unbound concentration ratios to in vivo p-glycoprotein efflux ratios. Drug Metab. Dispos. 2007, 35, 660-666.

${ }^{3}$ Murray, J. M.; Sweeney, Z. K.; Chan, B. K.; Balazs, M.; Bradley, E.; Castanedo, G.; Chabot, C.; Chantry, D.; Flagella, M.; Goldstein, D. M.; Kondru, R.; Lesnick, J.; Li, J.; Lucas, M. C.; Nonomiya, J.; Pang, J.; Price, S.; Salphati, L.; Safina, B.; Savy, P. P. A.; Seward, E. M.; Ultsch, M.; Sutherlin, D. P. Potent and Highly Selective Benzimidazole Inhibitors of PI3-Kinase Delta. J. Med. Chem. 2012, 55, 7686-7695. 